\title{
Promoting Forage Legume-Pollinator Interactions: Integrating Crop Pollination Management, Native Beekeeping and Silvopastoral Systems in Tropical Latin America
}

\section{OPEN ACCESS}

Edited by:

Eduardo Vázquez,

University of Bayreuth, Germany

Reviewed by:

Marta Cecilia Telesnicki,

University of Buenos Aires, Argentina Bruce Ferguson,

El Colegio de la Frontera Sur, Mexico

*Correspondence:

Stefan Burkart

s.burkart@cgiar.org

Specialty section:

This article was submitted to Climate-Smart Food Systems,

a section of the journal

Frontiers in Sustainable Food Systems

Received: 16 June 2021 Accepted: 27 August 2021 Published: 22 September 2021

Citation:

Narjes Sanchez ME, Cardoso

Arango JA and Burkart S (2021)

Promoting Forage Legume-Pollinator

Interactions: Integrating Crop

Pollination Management, Native

Beekeeping and Silvopastoral

Systems in Tropical Latin America.

Front. Sustain. Food Syst. 5:725981.

doi: 10.3389/fsufs.2021.725981

\author{
Manuel Ernesto Narjes Sanchez ${ }^{1,2}$, Juan Andrés Cardoso Arango $^{3}$ and Stefan Burkart ${ }^{3 *}$ \\ ${ }^{1}$ The Alliance of Bioversity International-CIAT, Multifunctional Landscapes, Cali, Colombia, ${ }^{2}$ University of Hohenheim, \\ Department of Production Theory and Resource Economics, Stuttgart, Germany, ${ }^{3}$ The Alliance of Bioversity \\ International-CIAT, Crops for Nutrition and Health, Tropical Forages Program, Cali, Colombia
}

Major declines of insect pollinators are a worldwide concern. Such losses threaten human food supplies and ecosystem functions. Monocultures of pastures used to feed cattle are among the drivers of insect pollinator declines in Tropical Latin America. Plants of the legume family (fabaceae) are mostly pollinated by insects, in particular by bees. The inclusion of legumes in pastures (grass-legume system), as forage banks or the development of silvo-pastoral systems (SPS) with tree legumes, has been widely promoted to improve livestock production and soil fertility, but not to enhance ecosystem services from pollinators. Shortages of seed for the establishment of legumes as forage banks or within pastures or SPS remain a bottleneck for the improvement of ecosystem services brought about by pollinators within these systems and beyond. In this perspective paper, we provide an overview of forage legumes, their interplay with pollinators, and the ecological and socio-economic benefits of pollinator-forage legume interactions, at different scales (farm and landscape level). We further discuss the challenges and opportunities of scaling sustainably intensified cattle production systems that integrate legume forage-seed production with principles of pollinator ecology and native beekeeping. Finally, we provide interested stakeholders, policy-and decision-makers with a perspective on how such agroecosystems may be designed and scaled into multifunctional landscapes.

Keywords: sustainable intensification, silvo-pastoral systems, cattle, forage legumes, meliponiculture, ecosystem services, pollinators, nature-based solutions

\section{INTRODUCTION}

There is a growing demand for livestock products (Bernabucci, 2019). Intensification of cattle production systems (i.e., increase in production per unit of available resource) is proposed to meet market requirements (Sakamoto et al., 2020), increase economic returns and reduce environmental impacts (Cassman and Grassini, 2020) including land use (Martha et al., 2012) and greenhouse gas (GHG) emissions (Eckard et al., 2010; Herrero et al., 2013; Ruviaro et al., 2015; Cardoso et al., 2016). Traditionally, cattle production systems in Tropical Latin America rely on grazing animals that feed upon planted or naturalized pastures. For intensification in this region, 
pastures tend to be dominated by a single species of a high yielding grass (da Silva et al., 2020), and subject to practices aimed to improve their productivity and nutritional quality. This includes aspects such as grazing management and the application of fertilizers, herbicides and pesticides (Gerssen-Gondelach et al., 2017). However, evidence indicates an association between intensified pastures and biodiversity loss (Bobbink et al., 2010; Fontana et al., 2016), including the decline of insect pollinators (Potts et al., 2010).

Insect pollinator decline is a major concern. Overcoming this declination is essential for global food security and ecosystem functioning (Van der Sluijs and Vaage, 2016; Van der Sluijs, 2020). The inclusion of legumes (fabacea) is a nature positive action to increase plant diversity within a pasture. Most legumes are pollinated by insects (Suso et al., 2016), suggesting that legume inclusion in pastures might provide ecosystem services coming from pollination. Orford et al. (2016) showed that modest enhancements to pasture diversity can improve the provision of pollination services to surrounding habitats. Furthermore, the inclusion of legumes brings other benefits to improve the efficiency and sustainability of cattle production systems (see sustainable intensification of livestock production systems, Rao et al., 2015). Benefits of legumes introduction include: (1) increases in quantity and quality of livestock feed and (2) soil improvement as a result of biological nitrogen fixation, soil stabilization and nutrient recycling (Schultze-Kraft et al., 2018). There is a wide variety of legumes available for cattle production (i.e., forage legumes). Forage legumes can be annual or perennial plants with different growth habits and various forms (i.e., herbaceous, shrub and tree legumes). The use of legumes in cattle production systems is not restricted to their inclusion in pastures as a grass-legume system. They are also used as forage banks (i.e., plant material used to supplement animal diets) or within silvopastoral systems (SPS).

SPS consist of diverse agroforestry arrangements that combine herbaceous plants, shrubs and trees for animal nutrition and complementary uses like timber or fruit production (Murgueitio et al., 2011). In particular, SPS with tree legumes are a promising nature-based solution to reduce the environmental impact of cattle production, while increasing its productivity, especially in Latin America (Dubeux et al., 2017; Chará et al., 2018; Landholm et al., 2019; Arango et al., 2020; Lira Junior et al., 2020). SPS arrangements might be in the form of scattered trees in pastures, pastures within tree alleys, living fences and windbreaks surrounding a pasture, to name a few (Murgueitio and Ibrahim, 2001; Murgueitio et al., 2011; Chará et al., 2018). SPS promote biodiversity by creating complex habitats that support a diverse above-ground flora and fauna, harbor a richer soil biota and improve connectivity between forest fragments (Ibrahim et al., 2006; Cubillos et al., 2016). At a landscape level, they provide more ecosystem services than open pastures (Calle et al., 2009; Murgueitio et al., 2011). In Brazil, the conversion from pasture monocultures to SPS has increased the abundance, richness and diversity of insects, including pollinators (Auad et al., 2015; Paiva et al., 2020).

Through its Global Action on Pollination Services for Sustainable Agriculture, the FAO has joined efforts with governments, research institutions and academia to coordinate the global implementation of the International Pollinator Initiative (IPI) (FAO, 2021). The IPI's plan of action offers guidelines for the improvement and development of practices that promote the conservation and sustainable use of pollinator diversity, restoring pollinator habitats in agriculture and related ecosystems (Byrne and Fitzpatrick, 2009; CBD, 2018). Since its launch at the 5th COP of the Convention on Biological Diversity in 2000, the IPI has catalyzed the development and implementation of several other initiatives both at the regional (e.g., the African Pollinator Initiative) and national (e.g., the Brazilian and Colombian Pollinator Initiatives) levels. For instance, the Colombian Pollinator Initiative (CPI) recognizes the contribution of pollination services to food security through the role pollinators play in the production of both crops and livestock, also identifying the expansion of cattle ranching as a major threat to pollinator habitats (Nates-Parra, 2016), building on a national strategy for the conservation and sustainable use of pollinators. Currently, Colombia's National Congress is considering a bill that establishes mechanisms for the conservation of pollinators and fosters the husbandry of native bee species. Although not explicitly stated in the CPI, its roadmap presents an opportunity for pursuing synergies with Colombia's COP21 Nationally Appropriate Mitigation Actions (NAMA) for the cattle sector.

Aligning national and/or regional pollinator initiatives with national efforts to reduce GHG emissions from cattle production may contribute to the 2030 Agenda for Sustainable Development. Pollinators can indeed be protected (i.e., UN-SDG 15: Life on land), by taking climate protection and adaptation concepts into account (i.e., UN-SDG 13: Climate action), while generating opportunities for employment and additional income in rural areas (i.e., UN-SDG 8: Decent work and economic growth) and pursuing other sustainable development goals. Costa Rica's Cattle NAMA, for example, seeks to achieve an eco-competitive sector that reconciles the goals of employment generation, biodiversity conservation and gender equality (UN-SDG 5) through the implementation of SPS (Ministerio de Agricultura y Ganadería, 2019). It recently completed its pilot phase, which preceded a first scaling effort aimed at reaching 5\% of Costa Rica's cattle farms. By 2030, Costa Rica expects upscaling to $27 \%$ of its farms (Climate Clean Air Coalition, 2020). NAMAs are one of several public policies that have seen advances promoting SPS as a silver-bullet solution for the sustainable intensification of the cattle sector, such as has been the case of Colombia (Ministerio de Agricultura y Desarrollo Rural, 2019, 2020), Argentina (Presidencia de la Nación Argentina, 2018) and Costa Rica (Ministerio de Agricultura y Ganadería, 2011). A limited availability of legume seed, which depends on animal-mediated pollination for its production, may nevertheless hamper scaling efforts for sustainably intensified cattle systems and thus limit their potential to deliver ecological, environmental and socioeconomic benefits at larger scales (Rao et al., 2015; Rubyogo et al., 2019; Arango et al., 2020).

This perspective paper provides an overview of forage legumes and agroecosystem management tools, available to 
cattle systems for the conservation of insect pollinators, optimization of crop-pollination services and tackling legume forage-seed bottlenecks. We discuss the opportunities and challenges of integrating principles of pollinator ecology and native beekeeping into SPS and artisanal and largescale propagation of legume forage-seeds. Finally, we provide interested stakeholders, policy- and decision-makers with a perspective on how such agroecosystems may be designed as mosaics or scaled into multifunctional landscapes. This article is structured as follows: The Forage Legume Seed Bottleneck section provides an overview on the limitation that a forage seed bottleneck currently imposes on the widespread adoption of SPS and grass-legume systems, and the role that pollinators can play in tackling this challenge. In Benefits of Bee Pollination on Legume Seed Production section, we present a list of interventions that can be implemented at the farm and landscape levels. We continue in the Proposed Interventions Section discussing macro-level conditions required to enable the implementation and guarantee the sustainability of the proposed interventions. Finally, the Required Enabling (Macro) Conditions Section offers concluding remarks and recommendations.

\section{THE FORAGE LEGUME SEED BOTTLENECK}

The benefits of introducing forage legumes into cattle production systems have been highlighted in numerous occasions (SchultzeKraft et al., 2018 and references therein). However, widespread adoption of forage legumes in Tropical Latin America is very low (see Muir et al., 2017). Seed scarcity is one of the reasons limiting a wider use of forage legumes into cattle production systems in Tropical Latin America. This hinders the implementation of more sustainable, yet intensified, cattle production systems in the region. Several projects, such as the Sustainable Colombian Cattle Project, support and promote the use of SPS through establishing pilot/reference farms for scaling, and although these projects have made significant advances, e.g., the establishment of 35,500 hectares of SPS in Colombia (Ganadería Colombiana Sostenible, 2018), once they end, a widespread adoption of these systems may be limited by legume seed scarcity.

Even though there is a strong private tropical forage seed sector in Brazil and Mexico, its focus is set on Gramineae seed production, which leaves legume seeds largely neglected. This bottleneck could thus be tackled by having these companies add legume seeds to their portfolio. Alternatively, artisanal on-farm legume seed production could be integrated into the overall design of sustainably intensified systems (Peters et al., 2003; Chakoma and Chummun, 2019; Philp et al., 2019; Rubyogo et al., 2019), taking advantage of the numerous possible interactions between legume cultivars and local plant-pollinator networks (Palmer et al., 2009; Boelt et al., 2015; Suso et al., 2016; Cong et al., 2020). This approach offers the potential added benefit of income diversification and employment creation among smallholders.

\section{BENEFITS OF BEE POLLINATION ON LEGUME SEED PRODUCTION}

The role of pollination in legume seed formation and yield depends on these plants' species-specific reproductive systems. While many forage legumes require insects (i.e., bees) for their pollination (i.e., out-crossing plants), others, including most tropical forage legumes, are self-pollinating (Kumar et al., 2020). Many self-pollinating legumes, however, exhibit an increased seed formation when their flowers are visited by bees (Palmer et al., 2009).

With the exceptions of trees in SPS, both forage banks and grass-legume systems are intensively managed to minimize flowering of plants (i.e., no pollination service). In contrast, the set-up of legume seed production sites allows the creation of gardens for wild and managed bees (i.e., both introduced, such as Apis mellifera, and native). Tropical forage legumes are numerous and highly diverse (see www.tropicalforages.info; Cook et al., 2020). The large diversity of tropical forage legumes allows the design of diverse garden blends that can provide a rich source of nectar and pollen for bees. The inclusion of several forage legumes for seed production can also support differences in flowering times, thereby offering foraging sites throughout the year for a higher bee diversity. Pollination gardens are a doublee win, since they (i) enhance the abundance, diversity, and community composition of bees and other pollinators, whose populations are threatened to decline due to agricultural intensification (Kovács-Hostyánszki et al., 2017) and climate change, especially in the tropics (Forrest, 2017); and (ii) increase pollinator visitation rates of bees to legume flowers, resulting in higher seed yields (Suso et al., 2016). Table 1 offers a list of herbaceous and tree legumes known to be self-pollinated but with increased out-crossing when visited by different bee species.

\section{PROPOSED INTERVENTIONS}

Table 2 presents various potential interventions at different levels (farm to landscape) and sectors (private and public) with the aim to promote the use of legumes as a naturebased solution that facilitate pollination services from insects, whilst allowing sustainable intensification of cattle production systems. Furthermore, these interventions allow the creation of seed production enterprises and different revenue avenues (e.g. meliponiculture).

\section{REQUIRED ENABLING (MACRO) CONDITIONS}

National Development Plans and other policies, e.g., in Colombia, Argentina or Costa Rica, increasingly outline the need for establishing SPS and other legume-based options as strategies for sustainable intensification of cattle farming, creating a demand for forage legume seed production (Ministerio de Agricultura y Ganadería, 2011; Presidencia de la Nación Argentina, 2018; Ministerio de Agricultura y Desarrollo Rural, 2019, 2020). Such demand is crucial for establishing large- 
TABLE 1 | List of herbaceous and tree legumes known to be self-pollinated but with increased out-crossing when visited by different bee species.

\begin{tabular}{|c|c|c|c|c|}
\hline Species & $\begin{array}{l}\text { Plant growth } \\
\text { habit }\end{array}$ & References for out-crossing legumes & $\begin{array}{l}\text { Pollinating bee species; bee } \\
\text { species relevant for } \\
\text { meliponiculture? (Yes/No) }\end{array}$ & Interaction type \\
\hline Cajanus cajan & Herbaceous & Saxena et al. (1994) & $\begin{array}{l}\text { Pollinating bee spp. unknown to } \\
\text { the authors }\end{array}$ & \multirow[b]{2}{*}{$\begin{array}{l}\text { Flower visitations with no } \\
\text { reference to specific floral } \\
\text { resource }\end{array}$} \\
\hline Centrosema spp. & Herbaceous & $\begin{array}{l}\text { Spears (1987), Miles et al. (1990), Maass and } \\
\text { Torres (1992, 1998) }\end{array}$ & $\begin{array}{l}\text { Centris (Centris) aenea, Centris } \\
\text { (Hemisiella) trigonoides, Centris } \\
\text { (Centris) flavifrons, Centris } \\
\text { (Trachina) sp. (No) }\end{array}$ & \\
\hline Desmodium spp. & Herbaceous & $\begin{array}{l}\text { Hutton (1960), Rotar and Urata (1967), } \\
\text { Quesenberry et al. (1989) }\end{array}$ & $\begin{array}{l}\text { Centris (Hemisiella) tarsata, } \\
\text { Thygater aethiops; (No) }\end{array}$ & $\begin{array}{l}\text { Flower visitations with no } \\
\text { reference to specific floral } \\
\text { resource }\end{array}$ \\
\hline Gliricidia sepium & Tree & $\begin{array}{l}\text { Dawson et al. (1997), Srinivasa Rao et al. } \\
\text { (2011) }\end{array}$ & $\begin{array}{l}\text { Xylocopa frontalis; (No) } \\
\text { Bombus pullatus; (No) } \\
\text { Melipona favosa, Tetragonisca } \\
\text { angustula; (Yes) }\end{array}$ & $\begin{array}{l}\text { Foraging for pollen } \\
0 \\
0 \\
0 \\
0 \\
0 \\
0\end{array}$ \\
\hline
\end{tabular}

The names of the bee species and the corresponding interaction types that are listed on this table were obtained from Nates-Parra (2016).

or small-scale seed production systems that integrate local plant-pollinator networks. These policies, however, lack the inclusion of pollinators and the ecosystem services they provide. Likewise, payment schemes for ecosystem services, such as for the establishment of SPS (e.g., Diaz et al., 2019a,b), do not include forage legume seed production models and pollinator ecosystem services.

Sustainable intensification strategies are a subject of algid debate. Despite the positive impacts of incorporation of forage legumes on cattle production systems (e.g., GHG emission reductions, animal welfare, biodiversity or land sparing) (Jansen et al., 1997; Rivas and Holmann, 2000; Peters et al., 2001; Valentim and Andrade, 2005; Enciso et al., 2019), an increased profitability of the system could be a driver for further expansion of the agricultural frontier at the expense of forests or protected ecosystems (Kaimowitz and Angelsen, 2008; Peñuela et al., 2011, 2014; CIAT and Cormacarena, 2017). This is likely to happen on marginal lands (Maertens et al., 2006; Barretto et al., 2013), cheap lands (White et al., 2001) or where land tenure is unclear (Kubitza et al., 2018). To counteract such developments, public policies (e.g., the Zero-Deforestation Agreements in Colombia and Brazil or the Brazilian Forest Code) (Presidência da República, 2012; Gibbs et al., 2015; FAO, 2016; Alianza Colombia TFA, 2021), safeguards and comprehensive monitoring/control mechanisms are required. Other instruments such as taxes, subsidies and land tenure rights are also needed (Cohn et al., 2014; de Oliveira Silva et al., 2016).

Investing in sustainable intensification strategies, smallholder legume seed production systems and meliponiculture require access to credit and inputs. Some advances stand out, such as credit lines destined to the establishment of SPS in Colombia (Ministerio de Agricultura y Desarrollo Rural, 2020). However, more access to credit is still missing for the establishment of seed multiplication plots and integrated meliponiculture. Resolving this bottleneck is crucial for assuring continuous seed supply, ecosystem services and the scaling up of SPS. Supporting the 
TABLE 2 | List of potential interventions considering legume-pollinator interactions.

\begin{tabular}{ll}
\hline Intervention & Description \\
\hline $\begin{array}{l}\text { Farm-level interventions } \\
\text { production }\end{array}$ & For own intensification purposes or as a business model to \\
& supply other producers who are intensifying or renewing their \\
& systems. Small-holder on-farm legume seed production should \\
& take account of local knowledge (i.e., the use of already present \\
& legumes in a particular area combined with local knowledge of \\
& the given species). Seed production systems should also \\
& consider the processes of selection, conservation and \\
& exchanging of locally adapted legumes by local farmers \\
& Organizing framework that structures the development and \\
& evaluation of efficient and flexible crop pollination strategies \\
Integrated crop pollination (ICP) & around the use of managed pollinator species in combination \\
& with farm management practices. It focuses on integrating and \\
& diversifying pollinators, after balancing the pros and cons of \\
& using a single managed bee species, or mixtures of managed \\
& bee species and/or wild pollinators. In addition to the use of wild \\
& and managed bee species, ICP encompasses various strategies \\
that enhance the farm environment for pollinators, including \\
directed habitat management and pesticide stewardship. These \\
strategies can be combined and adapted to the economic \\
constraints of each specific farm by using decision support tools \\
that consider crop value, yield benefits and the costs of adopting \\
each alternative ICP component and practice Garibaldi et al., \\
2017; Isaacs et al., 2017
\end{tabular}

Meliponiculture and other forms of In addition to the introduced European honeybee (A. mellifera), traditional beekeeping

Silvo-pastoral systems

Public and private sector interventions other bees that can be managed for their hive products and crop pollination include many stingless bee species (Hymenoptera: Apidae: Meliponini), which constitute the most diverse group of eusocial tropical bees, the Asian honeybee ( $A$. cerana) and a few Bombus species that are only reared for their crop pollination services. The integration of meliponiculture (i.e., keeping and managing native stingless bee species) in legume seed production systems can benefit farmers directly, through revenues from selling hive products, and indirectly due to an improved crop pollination, including that of legume forages. Beekeeping may also help raise the awareness of farmers with regard to the importance of adopting pollinator-friendly farm practices (e.g., sowing annual flowering plant strips to offer floral resources for pollinators throughout the year, integrated pest management, reduced insecticide application and minimizing pollinator poisoning by limiting insecticide applications to periods of low pollinator activity)

The versatility of SPS allows matching plant functional groups-including multiple leguminous herb, shrub and tree species-with pollinator functional groups Fontaine et al., 2006; Woodcock et al., 2014

\section{Landscape restoration approach}

Large scale legume seed production through the private seed sector farm level, yet pollinators are mobile organisms with foraging behaviors that cover distances between a few hundred meters to several kilometers. They are thus affected by the availability of resources and nesting sites at the landscape scale Pufal et al., 2017. The ecological effectiveness of the proposed interventions can therefore be maximized by integrating them into SPS that are planned, co-designed, coordinated and implemented at the landscape scale with the participation of local communities, local administrations, ecological restoration experts and environmental authorities. The versatility of legume-based SPS systems (e.g., with a high densities of tree legumes in combination with herbaceous legumes and with improved grasses) makes them especially suitable to restore the connectivity of fragmented landscapes, as their components (e.g., live fences, scattered trees and riparian buffers) can be arranged to provide ecologically important structural elements, such as connectivity corridors and hedgerows, thereby creating complex habitats for other wild animals and plants Murgueitio et al., 2011; Chará et al., 2019 As a company business model or through the integration of smallholder seed producers

\section{Potential benefits}

Income diversification and additional income (seed sales), support of sustainable intensification (scaling), provision of habitats for pollinators (ecosystem services), employment creation and opportunities for women and rural youth (preventing migration to cities)

Maximization of economic returns from pollinator-dependent crops, resilience to crop-pollination threats, additional income from hive product revenues, benefits from other enhanced farmland ecosystem services, reduced health risks from occupational and dietary exposure to pesticides

Income diversification and additional income (hive products, legume seed sales and increased yields of other pollinator dependent crops), home production and consumption of honey and propolis with characteristic physicochemical properties linked to traditional medicine, preservation of traditional knowledge and practices, employment creation (including the establishment of a local industry of handcrafted wooden beehives and the commercialization of other beekeeping supplies), benefits from other enhanced farmland ecosystem services and opportunities for women and youth in rural communities, which can help preventing rural exodus

Promote biodiversity and enhance ecosystem services beyond carbon sequestration Phelan et al., 2015; Suso et al., 2016; Wu et al., 2017; Otieno et al., 2020

Biodiversity conservation, supply of multiple ecosystem services that include improved local climate regulation and protection, water availability and a diverse cultural landscape with potential touristic attractiveness.
Support of sustainable intensification (scaling), standardization of seed quality, provision of habitats for pollinators (ecosystem services), employment creation, opportunities for women and rural youth (preventing migration to cities) 
organization of both cattle and seed producers could help in facilitating credit access and coordination of investment efforts. Likewise, the development of payment schemes for ecosystem services, incentives or new value chains with differentiated products (e.g., sustainable beef, honey) (Charry et al., 2019) could contribute to financing such investments at the farm level. Another financing model could be a cooperation amongst seed producers/beekeepers and companies who wish to green their image and are willing to finance the establishment of local seed production plots with integrated meliponiculture.

The establishment of seed multiplication plots, seed marketing and beekeeping also require access to different knowledge sets, such as legume seed production, treatment and marketing, beekeeping, and honey production, or product differentiation. Already existing knowledge should be integrated into the rural extension system, which also needs to be strengthened in reach and content (i.e., harmonization of different approaches to assure homogeneity of concepts and avoid confusion among producers) (Bravo et al., 2018; Charry et al., 2018; Enciso et al., 2018). Knowledge that helps to put the innovations into practice and facilitates scaling processes should be generated through research, i.e., regarding the adaptation to and selection of legumes for specific agro-ecological conditions and seed production, bee species for integrated meliponiculture, the ecology of plant-pollinator interactions, or pollinator diseases and invasiveness. Likewise, research should focus on the additional environmental and productive benefits of legume seed production with integrated meliponiculture, e.g., regarding GHG emissions, biodiversity, soil health, profitability or risk.

There is a vast diversity of forage legumes, of which a sample is safeguarded in the CGIAR gene banks (i.e., over 22,000 accessions of 72 species). Although the CGIAR gene banks hold the world's largest collection of tropical forage species (Alliance of Bioversity International-CIAT, 2020), this remains as a largely unexplored source of genetic material, key for the evaluation of legumes for sustainable intensification scenarios, seed production and integrated meliponiculture.

Regarding meliponiculture, legislation and codes of practice, such as those established by Colombia's Corporation for the Sustainable Development of the Southern Amazon (Corpoamazonia, 2016), must be set in place and enforced in order to avoid the overexploitation of native stingless bees, while promoting their sustainable use and propagation by smallholders and beekeepers. This is important considering the threat that the extraction and relocation of stingless bee colonies from their habitats imposes to their wild populations, not least because of the spatiotemporal dynamics of the parasites and diseases they carry. Additionally, research efforts need to be directed at harmonizing quality standards and export requirement specifications for the diversity of stingless bee honeys, in order to meet their increasing global demand as food and/or medicine, which could be seen as an additional opportunity for improved and diversified rural livelihoods.
Compared to grass monoculture pastures, which when largely expanded are associated with a homogenized vegetation and the application of insecticides and herbicides, silvo-pastoral systems improve biodiversity and offer promising results regarding the restoration of habitats and pollinator populations in agroecosystems, especially if combined with integrated crop pollination and native beekeeping. Nevertheless, research and adaptive farm management efforts should be considered for each agroecological context in order to leverage the potential pollinator conservation synergies from the interaction between traditional management practices and the natural regeneration processes of legume populations in legume-based silvo-pastoral systems.

\section{CONCLUDING REMARKS AND LOOK FORWARD}

The development of pollinator friendly environments, based on forage-legumes and SPS and their introduction into cattle systems, brings several benefits, including the (i) provision of habitats for pollinators on decline, and (ii) promotion of legume seed yield considered as barrier to the wider adoption of grass-legume, forage banks, or tree legume systems such as SPS. Higher seed yield makes it easier for seed producers to establish a business model to supply others to intensify or renew their forage-based cattle systems. It also allows the creation of different revenues such as those coming from bee farming (i.e., meliponiculture). The benefits from the interplay of pollinators and forage legumes can be further extended to the landscape level, affecting positively the yield of nearby pollinator-dependent crops. Furthermore, benefits of pollinators from cattle production systems can extend upon nearby ecosystems that might be fragmented or under decline due to several factors. For these pollination-based benefits to occur, enabling conditions, including policies, payment schemes for ecosystem services, incentives or new value chains, must be in place.

Seed availability is a bottleneck for the inclusion of legumes in cattle production systems at scale. It is noteworthy, however, that small scale cattle producers in Tropical Latin America often use and conserve native legumes in their production systems. These small-scale producers can be considered guardians of legume diversity and related knowledge (e.g., management and synergies/antagonism between grasses and legumes). Sadly, this knowledge is often neglected by topdown approaches driven by researchers or business interests. To counteract this shortcoming, approaches are needed that recognize small cattle producers' knowledge, and that foster their strategies for integrating legumes into their local farming systems in a sustainable and profitable manner. Likewise, increasing the forage legume seed availability might not result in impacts at scale unless measures are introduced and disseminated among farmers to ensure pasture management that favors the inclusion of legumes. In this sense, research 
and incentives are needed regarding, for example, rotational grazing and grazing pressure, weeding, burning, the use of agrochemicals, and the selection of Gramineae compatible with legume species.

\section{DATA AVAILABILITY STATEMENT}

The original contributions presented in the study are included in the article/supplementary material, further inquiries can be directed to the corresponding author.

\section{AUTHOR CONTRIBUTIONS}

MN, JC, and SB: conceptualization, methodology, formal analysis, writing the original draft and review and editing, and resources. SB and JC: supervision and funding acquisition and project administration. All authors contributed to the article and approved the submitted version.

\section{REFERENCES}

Alianza Colombia TFA (2021). Cero deforestación en Colombia: ABC de las cadenas cero deforestación de palma, cacao, carne y leche en Colombia. Bogotá, Colombia. Available online at: https://bit.ly/3g6dW8J (accessed September 03, 2021).

Alliance of Bioversity International-CIAT (2020). Tropical Forage Diversity. Available online at: https://ciat.cgiar.org/what-we-do/crop-conservation-anduse/tropical-forage-diversity/ (accessed September 03, 2021).

Arango, J., Ruden, A., Martinez-Baron, D., Loboguerrero, A. M., Berndt, A., Chacón, M., et al. (2020). Ambition meets reality: achieving ghg emission reduction targets in the livestock sector of Latin America. Front. Sustain. Food Syst. 4:65. doi: 10.3389/fsufs.2020.00065

Auad, A. M., Braga, A. F. L., Fonseca, M. G., Resende, T. T., Toledo, A. M. O., Lucindo, T. S., et al. (2015). Does the silvopastoral system alter hymenopteran fauna (insecta: hymenoptera) in brachiaria decumbens monocultures? Ann. Entomol. Soc. Am. 108, 468-473. doi: 10.1093/aesa/sav035

Barretto, A. G. O. P., Berndes, G., Sparovek, G., and Wirsenius, S. (2013). Agricultural intensification in Brazil and its effects on land-use patterns: an analysis of the 1975-2006 period. Glob. Change Biol. 19, 1804-1815. doi: $10.1111 /$ gcb. 12174

Bernabucci, U. (2019). Climate change: impact on livestock and how can we adapt. Anim. Front. 9, 3-5. doi: 10.1093/af/vfy039

Bobbink, R., Hicks, K., Galloway, J., Spranger, T., Alkemade, R., Ashmore, M., et al. (2010). Global assessment of nitrogen deposition effects on terrestrial plant diversity: a synthesis. Ecol. Appl. 20, 30-59. doi: 10.1890/08-1140.1

Boelt, B., Julier, B., Karagić, D., and Hampton, J. (2015). Legume seed production meeting market requirements and economic impacts. Crit. Rev. Plant Sci. 34, 412-427. doi: 10.1080/07352689.2014.898477

Bravo, A., Enciso, K., Hurtado. J. J., del Cairo, J. R., Jäger, M., Charry, A., et al. (2018). Estrategia sectorial de la cadena de ganadería doble propósito en Guaviare, con enfoque agroambiental y cero deforestación. Publicación CIAT No. 453. Centro Internacional de Agricultura Tropical (CIAT), Cali, Colombia. Available online at: https://hdl.handle.net/10568/91289 (accessed September 03, 2021).

Byrne, A., and Fitzpatrick, Ú. (2009). Bee conservation policy at the global, regional and national levels. Apidologie 40, 194-210. doi: 10.1051/apido/2009017

Calle, A., Montagnini, F., and Zuluaga, A. F. (2009). Farmers' perceptions of silvopastoral system promotion in Quindío, Colombia. Bois For. Trop. 300, 79-94. Available online at: http://bft.cirad.fr/cd/BFT_300_79-94.pdf. doi: 10.19182/bft2009.300.a20417

\section{FUNDING}

This work was funded by the CGIAR Research Program on Livestock. The funders had no role in the design of the study; in the collection, analyses, or interpretation of data; in the writing of the manuscript, or in the decision to publish the results. We also acknowledge the financial assistance of GROW Colombia from the UK Research and Innovation (UKRI) Global Challenges Research Fund (GCRF) (BB/P028098/1).

\section{ACKNOWLEDGMENTS}

This work was carried out as part of the CGIAR Research Program on Livestock. We thank all donors who globally support our work through their contributions to the CGIAR System. CGIAR is a global research partnership for a food-secure future. Its science is carried out by 15 Research Centers in close collaboration with hundreds of partners across the globe. We also thank the reviewers for their constructive comments that helped to improve the manuscript.

Cardoso, A. S., Berndt, A., Leytem, A., Alves, B. J. R., Carvalho, I. N. O., Barros Soares, L. H., et al. (2016). Impact of the intensification of beef production in Brazil on greenhouse gas emissions and land use. Agric. Syst. 143, 86-96. doi: 10.1016/j.agsy.2015.12.007

Cassman, K. G., and Grassini, P. (2020). A global perspective on sustainable intensification research. Nat Sustain 3, 262-268. doi: $10.1038 /$ s41893-020-0507-8

CBD (2018). Convention on Biological Diversity, Subsidiary Body on Scientific, Technical and Technological Advice 22nd meeting of SBSTTA "Conservation and Sustainable use of Pollinators", Montreal, Canada 2018.

Chakoma, I., and Chummun, B. Z. (2019). Forage seed value chain analysis in a subhumid region of Zimbabwe: perspectives of smallholder producers. Afric. J. Range Forage Sci. 36, 95-104. doi: 10.2989/10220119.2018.1546229

Chará, J., Reyes, E., Peri, P., Otte, J., Arce, E., and Schneider, F. (2018). Silvopastoral Systems and their Contribution to Improved Resource Use and Sustainable Development Goals (SDG): Evidence from Latin America. Geneva: Food and Agriculture Organization of the United Nations (FAO), Centre for Research on Sustainable Agriculture (CIPAV), Agri Benchmark. Available online at: http:// www.fao.org/3/ca2792en/ca2792en.pdf (accessed September 03, 2021).

Chará, J., Reyes, E., Peri, P., Otte, J., Arce, E., and Schneider, F. (2019). Silvopastoral Systems and their Contribution to Improved Resource Use and Sustainable Development Goals: Evidence from Latin America. Cali: FAO, CIPAV and Agri Benchmark, 60. Available online at: http://www.fao.org/3/ca2792en/ca2792en. pdf (accessed September 03, 2021).

Charry, A., Jäger, M., Enciso, K., Romero, M., Sierra L., Quintero, M., et al. (2018). Cadenas de valor con enfoque ambiental y cero deforestación en la Amazonía colombiana - Oportunidades y retos para el mejoramiento sostenible de la competitividad regional. CIAT Políticas en Síntesis No. 41. Centro Internacional de Agricultura Tropical (CIAT), Cali, Colombia. 10 p. https://hdl.handle.net/10568/97203 (accessed September 03, 2021).

Charry, A., Narjes, M., Enciso, K., Peters, M., and Burkart, S. (2019). Sustainable intensification of beef production in Colombia-chances for product differentiation and price premiums. Agric. Food Econ. 7:22. doi: 10.1186/s40100-019-0143-7

CIAT and Cormacarena (2017). Plan regional integral de cambio climático para la Orinoquía. CIAT publicación No. 438. Cali, Colombia: Centro Internacional de Agricultura Tropical (CIAT). Available online at: https://issuu.com/ juanpablomaringarcia/docs/evidencia_5.compressed (accessed September 03, 2021).

Climate and Clean Air Coalition (2020). Enhancing climate ambition and action in Costa Rica. Available online at: https://www.ccacoalition.org/en/activity/ 
enhancing-climate-ambition-and-action-costa-rica (accessed September 03, 2021).

Cohn, A. S., Mosnier, A., Havlík, P., Valin, H., Herrero, M., Schmid, E., et al. (2014). Cattle ranching intensification in Brazil can reduce global greenhouse gas emissions by sparing land from deforestation. Proc. Natl. Acad. Sci. 111, 7236-7241. doi: 10.1073/pnas.13071 63111

Cong, W., Dupont, Y. L., Søegaard, K., and Eriksen, J. (2020). Optimizing yield and flower resources for pollinators in intensively managed multi-species grasslands. Agric. Ecosyst. Environ. 302:107062. doi: 10.1016/j.agee.2020.1 07062

Cook, B. G., Pengelly, B. C., Schultze-Kraft, M., Taylor, M., Burkart, S., Cardoso Arango, J. A., et al. (2020). Tropical Forages: An Interactive Selection Tool. 2nd and Revised Edn. CIAT (International Center for Tropical Agriculture) and ILRI (International Livestock Research Institute). Available online at: www. tropicalforages.info

Corpoamazonia (2016). Aprobada la Gestión de CORPOAMAZONIA en el Marco del Plan de Acción 2016-2019 "Ambiente para la Paz". Mocoa, Colombia. Accessed on August 10 2021. Available online at: https://www.corpoamazonia. gov.co/index.php/noticias/1060-aprobada-gestion-corpoamazonia-20162019-ambiente-para-la-paz.

Cubillos, A. M., Vallejo, V. E., Arbeli, Z., Terán, W., Dick, R. P., Molina, C. H., et al. (2016). Effect of the conversion of conventional pasture to intensive silvopastoral systems on edaphic bacterial and ammonia oxidizer communities in Colombia. Eur. J. Soil Biol. 72, 42-50. doi: 10.1016/j.ejsobi.2015.12.003

da Silva, F. S., Domiciano, L. F., Gomes, F. J., Sollenberger, L. E., Pedreira, C. G. S., Pereira, D. H., et al. (2020). Herbage accumulation, nutritive value and beef cattle production on marandu palisadegrass pastures in integrated systems. Agrofor. Syst. 94, 1891-1902. doi: 10.1007/s10457-020-00508-3

Dawson, I. K., Waugh, R., Simons, A. J., and Powell, W. (1997). Simple sequence repeats provide a direct estimate of pollen-mediated gene dispersal in tropical tree Gliricidia sepium. Mol. Ecol. 6, 179-183. doi: 10.1046/j.1365-294X.1997.00163.x

de Oliveira Silva, R., Barioni, L. G., Hall, J. A. J., Matsuura, M. F., Albertini, T. Z., Fernandes, F. A., et al. (2016). Increasing beef production could lower greenhouse gas emissions in Brazil if decoupled from deforestation. Nat. Clim. Change 6, 493-497. doi: 10.1038/nclimate2916

Diaz, M. F., Enciso, K., Triana, N., and Burkart, S. (2019b). Protocolo para la entrada en operación de esquemas de Pagos por Servicios Ambientales para sistemas silvopastoriles. Publicación CIAT No. 488. Cali, CO: Centro Internacional de Agricultura Tropical (CIAT).Available online at: https://hdl. handle.net/10568/106846 (accessed September 03, 2021).

Diaz, M. F., Enciso, K., Triana, N., Muriel, J., and Burkart, S. (2019a). Pagos por Servicios Ambientales para sistemas silvopastoriles en Colombia. Cali, CO: Centro Internacional de Agricultura Tropical (CIAT). Available online at: https://hdl.handle.net/10568/106849 (accessed September 03, 2021).

Dick, C. W., Etchelecu, G., and Austerlitz, F. (2003). Pollen dispersal of tropical trees (Dinizia excelsa: Fabaceae) by native insects and African honeybees in pristine and fragmented Amazonian rainforest. Mol Ecol 12, 753-764. doi: $10.1046 /$ j.1365-294X.2003.01760.x

Dubeux, J. C. B., Jr., Muir, J. P., Apolinário, V. X. O., Ramachandran Nair, P. K., Lira, M. A. and Sollenberger, L. E. (2017). Tree legumes: an underexploited resource in warm-climate silvopastures. Braz. J. Anim. Sci. 46, 689-703. doi: 10.1590/S1806-92902017000800010

Dutech, C., Seiter, J., Petronelli, P., Joly, H. I., and Jarne, P. (2002). Evidence of low gene flow in a neotropical clustered tree species in two rainforest stands of French Guiana. Mol. Ecol. 11, 725-738. doi: 10.1046/j.1365-294X.2002.0 1475.x

Eckard, R. J., Grainger, C., and de Klein, C. A. M. (2010). Options for the abatement of methane and nitrous oxide from ruminant production: a review. Livestock Sci. 130, 47-56. doi: 10.1016/j.livsci.2010.02.010

Enciso, K., Bravo, A., Charry, A., Rosas, G., Jäger, M., Hurtado, J. J., et al. (2018). Estrategia sectorial de la cadena de ganadería doble propósito en Caquetá, con enfoque agroambiental y cero deforestación. Publicación CIAT No. 454. Cali, Colombia: Centro Internacional de Agricultura Tropical (CIAT). Available online at: https://hdl.handle.net/10568/91981 (accessed September 03, 2021).

Enciso, K., Sotelo, M., Peters, M., and Burkart, S. (2019). The inclusion of Leucaena diversifolia in a Colombian beef cattle production system: an economic perspective. Trop. Grasslands Forrajes Trop. 7, 359-369. doi: $10.17138 / \operatorname{tgft}(7) 359-369$

FAO (2021). The International Pollinator Initiative. Plan of action 2018-2030. Rome: FAO. Available online at: https://www.cbd.int/sbstta/sbstta-22-sbi-2/ sbstta-22-ipi-draft.pdf (accessed September 03, 2021).

FAO (2016). El Estado de los bosques del mundo 2016. Los bosques y la agricultura: desafíos y oportunidades en relación con el uso de la tierra. Rome, Italy: FAO. Availble online at: http://www.fao.org/documents/card/en/c/6547e46e3e6f-4c47-8dcb-8c5c19a18e00/ (accessed September 03, 2021).

Fontaine, C., Dajoz, I., Meriguet, J., and Loreau, M. (2006). Functional diversity of plant-pollinator interaction webs enhances the persistence of plant communities. PLoS Biol. 4:e1. doi: 10.1371/journal.pbio.0040001

Fontana, C. S., Dotta, G., Marques, C. K., Repenning, M., Agne, C. E., and dos Santos, R. J. (2016). Conservation of grassland birds in South Brazil: a land management perspective. Nat. Conser. 14, 83-87. doi: 10.1016/j.ncon.2016.09.005

Forrest, J. R. K. (2017). "Chapter 5. Insect Pollinators and Climate Change," in Global Climate Change and Terrestrial Invertebrates, eds. S.T. Johnson and T. Hefin Jones. New York, NY: Wiley. doi: 10.1002/9781119070894.ch5

Ganadería Colombiana Sostenible (2018). 'En qué consiste el proyecto Ganadería Colombiana Sostenible? Colombia. Available online at: https://bit.ly/32IkHat (accessed September 03, 2021).

Garibaldi, L. A., Requier, F., Rollin, O., and Andersson, G. K. S. (2017). Towards an integrated species and habitat management of crop pollination. Curr. Opin. Insect Sci. 21, 105-114. doi: 10.1016/j.cois.2017.05.016

Gerssen-Gondelach, S. J., Lauwerijssen, R. B. G., Havlík, P., Herrero, M., Valin, H., Faaij, A. P. C., et al. (2017). Intensification pathways for beef and dairy cattle production systems: Impacts on GHG emissions, land occupation and land use change. Agric. Ecosyst. Environ. 240, 135-147. doi: 10.1016/j.agee.2017.02.012

Gibbs, H. K., Munger, J., L'Roe, J., Barreto, P., Pereira, R., Christie, M., et al. (2015). Did ranchers and slaughterhouses respond to zero deforestation agreements in the Brazilian Amazon? Conserv. Lett. 9, 1-10. doi: 10.1111/conl.12175

Herrero, M., Havlík, P., Valin, H., Notenbaert, A., Rufino, M. C., and Thornton, P. K. (2013). Biomass use, production, feed efficiencies, and greenhouse gas emissions from global livestock systems. Proc. Natl. Acad. Sci. U. S. A. 110, 20888-20893. doi: 10.1073/pnas.1308149110

Hufford, K. M., and Hamrick, J. L. (2003). Viability selection at three early life stages of the tropical tree, Platypodium elegans (Fabaceae, Papilionoideae). Evolution 57, 518-526. doi: 10.1111/j.0014-3820.2003.tb01543.x

Hutton, E.M. (1970). Tropical pastures. Adv. Agron. 22, 1-73. doi: 10.1016/S0065-2113(08)60265-5

Hutton, E. M. (1960). Flowering and pollination in Indigoferaspicata, Phaseolus lathyroides, Desmodium uncinatum, andsome other tropical pasture legumes. J. Exp. Agric. 28, 235-243. Available online at: https://www.cabdirect.org/ cabdirect/abstract/19611600570 (accessed September 03, 2021).

Hutton, E. M. (1981). Natural crossing and acid tolerance in some Leucaena species. Leucaena Res. Rep. 2, 2-4. Available online at: https://www.cabi.org/ isc/abstract/19860610173 (accessed September 03, 2021).

Ibrahim, M., Villanueva, C., Casasola, F., and Rojas, J. (2006). Sistemas silvopastoriles como una herramienta para el mejoramiento de la productividad y restauración de la integridad ecológica de paisajes ganaderos. Past. Forrajes 29, 383-419. Available online at: https://www.redalyc.org/pdf/2691/ 269121676004.pdf (accessed September 03, 2021).

Isaacs, R., Williams, N., Ellis, J., Pitts-Singer, T. L., Bommarco, R., and Vaughan, M. (2017). Integrated crop pollination: combining strategies to ensure stable and sustainable yields of pollination-dependent crops. Basic Appl. Ecol. 22, 44-60. doi: 10.1016/j.baae.2017.07.003

Jansen, H. G. P., Ibrahim, M. A., Nieuwenhuyse, A., 't Mannetje, L., Joenje, M., and Abarca, S. (1997). The economics of improved pasture and silvopastoral technologies in the Atlantic zone of Costa Rica. Trop. Grassl. 31, 588-598. Available online at: https://www.tropicalgrasslands.info/public/journals/4/ Historic/Tropical\%20Grasslands\%20Journal\%20archive/Abstracts/Vol_31_ 1997/Abs_31_06_97_pp588_598.html (accessed September 03, 2021).

Kaimowitz, D., and Angelsen, A. (2008). Will livestock intensification help save latin America's tropical forests? J. Sustain. For. 27, 6-24. doi: $10.1080 / 10549810802225168$

Kovács-Hostyánszki, A., Espíndola, A., Vanbergen, A. J., Settele, J., Kremen, C., and Dicks, L. V. (2017). Ecological intensification to mitigate impacts of 
conventional intensive land use on pollinators and pollination. Ecol. Lett. 20, 673-689. doi: 10.1111/ele.12762

Kubitza, C., Krishna, V. V., Urban, K., Alamsyah, Z., and Qaim, M. (2018). Land property rights, agricultural intensification, and deforestation in Indonesia. Ecol. Econ. 147, 312-321. doi: 10.1016/j.ecolecon.2018.01.021

Kukade, S. A., and Tidke, J. A. (2014). Reproductive biology of Dolichos lablab L. (Fabaceae). Indian J. Plant Sci. 3, 22-25.

Kumar, A., Hanson, J., and Abdena, A. (2020). "Production of high-quality tropical forage legume seeds," in Advances in Seed Production and Management, eds. A. K. Tiwari. Singapore: Springer. doi: 10.1007/978-981-15-4198-8_6

Landholm, D. M., Pradhan, P., Wegmann, P., Sánchez Romero, M. A., Salazar Suárez, J. C., and Kropp, J. P. (2019). Reducing deforestation and improving livestock productivity: greenhouse gas mitigation potential of silvopastoral systems in Caquetá. Environ. Res. Lett. 14:114007. doi: 10.1088/1748-9326/ab3db6

Latouche-Hallé, C., Ramboer, A., Bandou, E., Caron, H., and Kremer, A. (2004). Long-distance pollen flow and tolerance to selfing in a neotropical tree species. Mol. Ecol. 13, 1055-1064. doi: 10.1111/j.1365-294X.2004.02127.x

Lira Junior, M. A., Fracetto Cury, F. J., Da Ferreira, J. S., Silva, M. B., Fracetto, M., and Gomes Monteiro, G. (2020). Legume silvopastoral systems enhance soil organic matter quality in a subhumid tropical environment. Soil Sci. Soc. Am. J. 84, 1209-1218. doi: 10.1002/saj2.20106

Loveless, M. D., Hamrick, J. L., and Foster, R. B. (1998). Population structure and mating system in Tachigali versicolor, a monocarpic neotropical tree. Heredity 81, 134-143. doi: 10.1046/j.1365-2540.1998.00353.x

Maass, B. L., and Torres, A. M. (1998). Off-types indicate natural outcrossing in five tropical forage legumes in Colombia. Trop. Grassl. 32, 124-130. Available online at: https://www.tropicalgrasslands.info/public/journals/4/Historic/ Tropical\%20Grasslands\%20Journal\%20archive/Abstracts/Vol_32_1998/Abs_ 32_02_98_pp124_130.html (accessed September 03, 2021).

Maass, B. L., and Torres, A. M. (1992). "Outcrossing in the tropical forage legume Centrosema brasilianum (L.) Benth," Abstracts of the XIII EUCARPIA Congress, Angers, France,1992, 465-466. Available online at: https://hdl.handle. net/10568/89580 (accessed September 03, 2021).

Maertens, M., Zeller, M., and Birner, R. (2006). Sustainable agricultural intensification in forest frontier areas. Agric. Econ. 34, 197-206. doi: 10.1111/j.1574-0864.2006.00118.x

Martha, G. B., Alves, E., and Contini, E. (2012). Land-saving approaches and beef production growth in Brazil. Agric. Syst. 110, 173-177. doi: 10.1016/j.agsy.2012.03.001

Miles, J. W. (1985). Evaluation of potential genetic marker traits and estimation of outcrossing rate in Stylosanthes guianensis. Aust. J. Agric. Res. 36, 259-265. doi: 10.1071/AR9850259

Miles, J. W., Clements, R. J., Grof,. B., and Serpa, A. (1990). "Genetics and breeding of Centrosema," in Centrosema: Biology, Agronomy, and Utilization, eds. R. Schultze-Kraft, R. J. Clements. CIAT publication no. 92. Colombia: Cali, 245-270. Available online at: https://library.ciat.cgiar.org/cgi-bin/koha/opacdetail.pl?biblionumber=23425 (accessed September 03, 2021).

Ministerio de Agricultura y Desarrollo Rural (2019). Política agropecuaria y de desarrollo rural 2018-2022: un campo para la equidad. Bogotá. Available online at: https://n9.cl/yjgle (accessed September 03, 2021).

Ministerio de Agricultura y Desarrollo Rural (2020). MinAgricultura Rodolfo Zea lanza nueva línea para financiar los sistemas silvopastoriles. Colombia. Available online at: https://bit.ly/3sNo6ze (accessed September 03, 2021).

Ministerio de Agricultura y Ganadería (2011). Política de Estado para el Sector Agroalimentario y el Desarrollo Rural Costarricense 2010-2021. Costa Rica. Available online at: https://bit.ly/2QlzRjr (accessed September 03, 2021).

Ministerio de Agricultura y Ganadería (2019). Costa Rica, en ruta hacia la descarbonización de la ganadería 2013-2018. San José: Costa Rica. Available online at: https://bit.ly/3najylF (accessed September 03, 2021).

Muir, J. P., Tedeschi, L. O., Dubeux, J. C. B., Peters, M., and Burkart, S. (2017). Enhancing food security in Latin America with forage legumes, Aumentar a segurança alimentar na América Latina com leguminosas forrageiras. Arch. Latinoamerican. Prod. Anim. 25, 113-131. Available online at: https://hdl. handle.net/10568/96233 (accessed September 03, 2021).

Murawski, D. A., and Hamrick, J. L. (1991). The effect of the density of flowering individuals on the mating systems of nine tropical tree species. Heredity 67, 167-174. doi: 10.1038/hdy.1991.76
Murgueitio, E., Calle, Z., Uribe, F., Calle, A., and Solorio, B. (2011). Native trees and shrubs for the productive rehabilitation of tropical cattle ranching lands. For. Ecol. Manag. 261, 1654-1663. doi: 10.1016/j.foreco.2010. 09.027

Murgueitio, E., and Ibrahim, M. (2001). "Agroforestería pecuaria para la reconversión de la ganadería en Latinoamérica," in Livestock Research for Rural Development 13. Available online at: http://www.lrrd.org/lrrd13/3/murg133. htm (accessed December 5, 2021).

Nates-Parra, G. (2016). Iniciativa Colombiana de Polinizadores-Abejasicpa. Bogotá, D. C.: Departamento de Biología, Universidad Nacional de Colombia. ISBN 978-958-775-866-5 (digital). Available online at: https://www. uneditorial.com/pageflip/acceso-abierto/pdf/abejas-polinizadoras-ebook40217.pdf (accessed September 03, 2021).

Nogueira Couto, R. H., Favoretto, V., Almeida, L. F., de Prandi, D. M., and de Andrade Rodriguez, L. R. (1997). Insect pollination and plant guiding in Galactia striata (Jacq.) Urb. (Leguminosae). Pasturas Trop. 19, 51-54. Available online at: https://www.tropicalgrasslands.info/public/journals/4/Elements/ DOCUMENTS/1997-vol19-rev1-2-3/Vol19_rev1_97_art10.pdf (accessed September 03, 2021).

Orford, K. A., Murray, P. J., Vaughan, I. P., and Memmott, J. (2016). Modest enhancements to conventional grassland diversity improve the provision of pollination services. J. Appl. Ecol. 53, 906-915. doi: 10.1111/1365-2664.12608

Otieno, M., Steffan-Dewenter, I., Potts, S. G., Kinuthia, W., Kasina, M. J., and Garratt, M. P. D. (2020). Enhancing legume crop pollination and natural pest regulation for improved food security in changing African landscapes. Glob. Food Secur. 26:100394. doi: 10.1016/j.gfs.2020.100394

Paiva, I. G., Auad, A. M., Veríssimo, B. A., and Silveira, L. C. P. (2020). Differences in the insect fauna associated to a monocultural pasture and a silvopasture in Southeastern Brazil. Sci. Rep. 10:12112. doi: 10.1038/s41598-020-68973-5

Palmer, R. G., Perez, P. T., Ortiz-Perez, E., Maalouf, F., and Suso, M. J. (2009). The role of crop-pollinator relationships in breeding for pollinatorfriendly legumes: from a breeding perspective. Euphytica 170, 35-52. doi: 10.1007/s10681-009-9953-0

Peñuela, L., Fernández, A. P., Castro, F., and Ocampo, A. (2011). Uso y manejo de forrajes nativos en la sabana inundable de la Orinoquía. Convenio de cooperación interinstitucional entre The Nature Conservancy (TNC) y la Fundación Horizonte Verde (FHV) con el apoyo de la Fundación Biodiversidad de España y la Corporación Autónoma Regional de la Orinoquía (CorpOrinoquía). Available online at: https://infopastosyforrajes.com/libros$y$-manuales-pdf/uso-y-manejo-de-forrajes-nativos-en-la-sabana-inundablede-la-orinoquia/ (accessed September 03, 2021).

Peñuela, L., Solano, C., Ardila, V., and Galán, S. (2014). Sabana inundable y ganadería, opción productiva de conservación en la Orinoquia. Bogotá, Colombia: Asociación Red Colombiana de Reservas Naturales de la Sociedad Civil, Fundación Natura, World Wildlife Fund, The Nature Conservancy, y Parques Nacionales Naturales de Colombia. Available online at: https://horizonteverde.org.co/wp-content/uploads/2020/02/LIBROGANADERO-G5-FINAL.pdf (accessed September 03, 2021).

Peters, M., Horne, P., Schmidt, A., Holmann, F., Kerridge, P. C., Tarawali, S. A., et al. (2001). The Role of Forages in Reducing Poverty and Degradation of Natural Resources in Tropical Production Systems. Agricultural Research and Extension Network. Network Paper No. 117. Available online at: https://cdn. odi.org/media/documents/5218.pdf (accessed September 03, 2021).

Peters, M., Lascano, C. E., Roothaert, R., and de Haan, N. C. (2003). Linking research on forage germplasm to farmers: the pathway to increased adoption-a CIAT, ILRI and IITA perspective. Field Crops Res. 84, 179-188. doi: 10.1016/S0378-4290(03)00149-7

Phelan, P., Moloney, A. P., McGeough, E. J., Humphreys, J., Bertilsson, J., O’Riordan, E. G., et al. (2015). Forage legumes for grazing and conserving in ruminant production systems. Crit. Rev. Plant Sci. 34, 281-326. doi: 10.1080/07352689.2014.898455

Philp, J. N. M., Vance, W., Bell, R. W., Chhay, T., Boyd, D., Phimphachanhvongsod, V., and et al. (2019). Forage options to sustainably intensify smallholder farming systems on tropical sandy soils. A review. Agron. Sustain. Dev. 39:30. doi: 10.1007/s13593-019-0576-0

Potts, S. G., Biesmeijer, J. C., Kremen, C., Neumann, P., Schweiger, O., and Kunin, W. E. (2010). Global pollinator declines: trends, impacts and drivers. Trends Ecol. Evol. 25, 345-353. doi: 10.1016/j.tree.2010.01.007 
Presidência da República (2012). Lei $\mathrm{N}^{\circ}$ 12.651, de 25 de maio de 2012. Dispõe sobre a proteção da vegetação nativa e dá outras providências. Presidência da República. Available online at: http://www.planalto.gov.br/ccivil_03/_ato20112014/2012/lei/L12651compilado.htm (accessed September 03, 2021).

Presidencia de la Nación Argentina (2018). Objetivos de desarrollo sostenible. Argentina. Available online at: https://bit.ly/3tlDzbb (accessed September 03, 2021).

Pritchard, A. J., and t' Mannetje, L. (1967). The breeding systems and some interspecific relations of a number of African Trifolium spp. Euphytica 16, 324-329. doi: 10.1007/BF00028938

Pufal, G., Steffan-Dewenter, I., and Klein, A.-M. (2017). Crop pollination services at the landscape scale. Curr. Opin Insect Sci. 21, 91-97. doi: 10.1016/j.cois.2017.05.021

Quesenberry, K. H., McKellar, M. A., and Moon, D. E. (1989). "Evaluation and hybridization of germplasm in the Desmodium heterocarpon-D. ovalifolium species complex," in Proceedings of the XVI International Grassland Congress, Nice, France, 1989, pp. 251-252. Association Francaise pour la Production Fourragere, Versailles (France): AFPF, 1989. ISBN 2-9504110-0-2, 251-252.

Rao, I., Peters, M., Castro, A., Schultze-Kraft, R., White, D., Fisher, M., et al. (2015). LivestockPlus-the sustainable intensification of forage-based agricultural systems to improve livelihoods and ecosystem services in the tropics. Trop. Grass Forr. Trop. 3:59. doi: 10.17138/TGFT(3)59-82

Ribeiro, R. A., and Lovato, M. B. (2004). Mating system in a neotropical tree species, Senna multijuga (Fabaceae). Genet. Mol. Biol. 27, 418-424. doi: 10.1590/S1415-47572004000300018

Rivas, L., and Holmann, F. (2000). Early adoption of Arachis pintoi in the humid tropics: the case of dual-purpose livestock systems in Caquetá, Colombia. Livestock Research for Rural Development, 12:Article\#23. Available online at: http://www.lrrd.org/lrrd12/3/riva123.htm (accessed September 03, 2021).

Rotar, P. P., and Urata, U. (1967). Cytological studies in the genus Desmodium; some chromosome counts. Am. J. Bot. 54, 1-4. doi: 10.2307/2440881

Rubyogo, J. C., Akpo, E., Omoigui, L., Pooran, G., Chaturvedi, S. K., and Fikre, A. (2019). Market-led options to scale up legume seeds in developing countries: experiences from the Tropical Legumes Project. Plant Breed. 138, 474-486. doi: 10.1111/pbr.12732

Ruviaro, C. F., de Léis, C. M., Lampert, V., do, N., Barcellos, J. O. J., and Dewes, H. (2015). Carbon footprint in different beef production systems on a southern Brazilian farm: a case study. J. Clean. Prod. 96, 435-443. doi: 10.1016/j.jclepro.2014.01.037

Sakamoto, L. S., Berndt, A. P., André de, F., Lemes, A. P., Azenha, M. V., Alves, T. C., et al. (2020). Pasture intensification in beef cattle production can affect methane emission intensity. In J. Anim. Sci. 98:skaa309. doi: 10.1093/jas/skaa309

Santos-Garcia, M. O., Resende, R. M. S., Chiari, L., Imaculada Zucchi, M., and Pereira de Souza, A. (2011). Mating systems in tropical forages: Stylosanthes capitata Vog. and Stylosanthes guianensis (Aubl.) Sw. Euphytica 178, 185-193. doi: 10.1007/s10681-010-0293-x

Saxena, K. B., Jayasekera, S. J. B. A., Ariyaratne, H. P., Ariyanayagam, R. P., and Fonseka, H. H. D. (1994). Frequency of natural out-crossing in partially cleistogamous pigeon pea lines in diverse environments. Crop Sci. 34, 660-662. doi: 10.2135/cropsci1994.0011183X003400030011x

Schultze-Kraft, R., Rao, I. M., Peters, M., Clements, R. J., Bai, C., and Liu, G. (2018). Tropical forage legumes for environmental benefits: an overview. Trop. Grassl. Forr. Trop. 6, 1-14. doi: 10.17138/TGFT(6)1-14

Spears, Jr., E.E. (1987). Island and mainland pollination ecology of Centrosema virginianum and Opuntia stricta. J. Ecol. 75, 351-362. doi: 10.2307/2260423
Srinivasa Rao, C., Venkateswarlu, B., Dinesh Babu, M., Wani, S. P., Dixit, S., Sahrawat, K. L., et al. (2011). Soil Health Improvement with Gliricidia Green Leaf Manuring in Rainfed Agriculture, on Farm Experiences. Santoshnagar: Central Research Institute for Dryland Agriculture, p. 16. Available online at: http://oar. icrisat.org/5534/ (accessed September 03, 2021).

Suso, M. J., Bebeli, P. J., Christmann, S., Mateus, C., Negri, V., and Pinheiro de Carvalho, M. A. A. (2016). Enhancing legume ecosystem services through an understanding of plantpollinator interplay. Front. Plant Sci. 7:333. doi: 10.3389/fpls.2016. 00333

Valentim, J. F., and Andrade, C. M. S. (2005). Forage peanut (Arachis pintoi): a high yielding and high-quality tropical legume for sustainable cattle production systems in the western Brazilian Amazon. Trop. Grassl. 39:222. Available online at: https://www.tropicalgrasslands.info/public/journals/4/Historic/Tropical \%20Grasslands\%20Journal\%20archive/PDFs/Vol_39_2005/Vol_39_04_2005_ pp222_222.pdf (accessed September 03, 2021).

Van der Sluijs, J. P. (2020). Insect decline, an emerging global environmental risk. Curr. Opin. Environ. Sustain. 46, 39-42. doi: 10.1016/j.cosust.2020.08.012

Van der Sluijs, J. P., and Vaage, N. S. (2016). Pollinators and global food security: the need for holistic global stewardship. Food Ethics 1, 75-91. doi: 10.1007/s41055-016-0003-z

White, D., Holmann, F., Fujisaki, S., Reategui, K., and Lascano, C. (2001). Will intensifying pasture management in Latin America protect forests-Or is it the other way around? Agricultural Technologies and Tropical Deforestation, eds. A. Angelsen, and D. Kaimowitz (Wallingford, UK: CABI Publishing), 91-113. doi: 10.1079/9780851994512.0091

Woodcock, B. A., Savage, J., Bullock, J. M., Nowakowski, M., Orr, R., Tallowin, J. R. B., et al. (2014). Enhancing floral resources for pollinators in productive agricultural grasslands. Biol. Conserv. 171, 44-51. doi: 10.1016/j.biocon.2014. 01.023

Wu, G. L., Liu, Y., Tian, F. P., and Shi, Z. H. (2017). Legumes functional group promotes soil organic carbon and nitrogen storage by increasing plant diversity. Land Degrad. Develop. 28, 1336-1344. doi: 10.1002/ldr. 2570

Author Disclaimer: The views expressed in this document may not be taken as the official views of these organizations.

Conflict of Interest: The authors declare that the research was conducted in the absence of any commercial or financial relationships that could be construed as a potential conflict of interest.

Publisher's Note: All claims expressed in this article are solely those of the authors and do not necessarily represent those of their affiliated organizations, or those of the publisher, the editors and the reviewers. Any product that may be evaluated in this article, or claim that may be made by its manufacturer, is not guaranteed or endorsed by the publisher.

Copyright (๑ 2021 Narjes Sanchez, Cardoso Arango and Burkart. This is an openaccess article distributed under the terms of the Creative Commons Attribution License (CC BY). The use, distribution or reproduction in other forums is permitted, provided the original author(s) and the copyright owner(s) are credited and that the original publication in this journal is cited, in accordance with accepted academic practice. No use, distribution or reproduction is permitted which does not comply with these terms. 